\title{
HILL MARI CONSONANT SYSTEM IN THE LANGUAGE EDUCATION OF FUTURE LANGUAGE TEACHERS
}

\author{
Nadezhda M. Krasnova ${ }^{1}$ and Galina A. Ertsikova ${ }^{2^{\star}}$ \\ ${ }^{1}$ Assoc. Prof. Dr., Mari State University, Russian Federation, krasnovanadezhda5@yandex.ru \\ ${ }^{2}$ Dr., Mari Research Institute after V.M. Vasilyev, Russian Federation, galina.ehrcikova@yandex.ru \\ ${ }^{*}$ Corresponding author
}

\begin{abstract}
The article describes the importance and peculiarities of Hill Mari consonant system in the language education of future language teachers. As one of the most neglected aspects of Hill Mari language teaching, pronunciation has not gained special attention for the last few years. Mainly, it is intended to be useful to students of philology and to those who are concerned with studying the consonant sounds in Hill Mari. In order to work on pronunciation of schoolchildren it is very important to know the classification of Hill Mari consonant phonemes, the particular quality of which depends on the work of the vocal cords. The article also reports on the classification of consonants according to different principles. Consonants in Hill Mari are classified in terms of the following factors: - state of the vocal folds; - position of the soft palate; - place of articulation; - manner of the production of noise.
\end{abstract}

Keywords: Language Education, Hill Mari, Consonants, Phonetics.

\section{INTRODUCTION}

As students of philology future school teachers of the Hill Mari language should know and understand the main mechanisms of speech production and perception, the difference between sounds and the meaning of words, the way sound systems are structures.

The article deals with the classification of Hill Mari consonants. A consonant is a sound produced with an obstruction to the air stream. The organs of speech are tense at the place of obstruction. In the articulation of voiceless consonants the air stream is strong, while in voiced consonants it is weaker.

Currently, the school is faced with the task of exercising the skills of modern pronunciation to provide further increasing the effectiveness of teaching and educating students.

The aim of the article is to provide explanation of how Hill Mari consonants are produced and perceived. It is known that any speech event is a complex process controlled by human brain. The members of the project asked Hill Mari speakers to read the text given bellow. The text is the original one and it contains all the Hill Mari phonemes. After analyzing recordings, the project members tried to present their classification of consonants in Hill Mari.

Müın' mÿländ̈̈n sek cever värb̈shẗ̈ızḧ̈ ̈̈lem - tid̈̈ mün'b̈n shanymashem. Tilec jazhom kb̈ichälät güinjat, at mo! Mämnän iziräk halanam kym tängem anzhalash tolynyt yl'y. Vätüızḧ̈ - klovoj sünzään cever Anna dono tolshyzhy, kudymshy i celinashty b̈lä. Ves̈̈ nauchnyj konferencivläshẗ̈l, bjuroshty jamyn kashtesh, no shukerd̈̈ agyl ẗ̈lb̈ cerlänen kolten dä mä donna shajyshtash vb̈ic-kud kechüm mon. Slabka ylmyzhy jeche shizhältb̈n: tb̈ld̈̈ v̈̈ld ẗ̈rr̈̈shtb̈ kisḧ̈ oshmam so vyrsen, shokshy igechüım jaryktyde dä shagalamykyna török molnamshyla pÿgürikäjesh pyren shünz̈̈n. Tangyzh jakte avtobusesh iktä nül chäs närb̈ kydalmyla. 
No palny vӹd vӹlec isḧ̈ osh, rozovyj, yzhar katerb̈m, vӹd̈̈n mychashdymy kymdykshym vele uzhash dä ̈̈lı̈̈mäsh török kushtylgemesh!

Irok ir̈̈ vӹd tb̈rb̈shtb̈ pasnaok tyr ylyn. Mälännä kÿshücb̈ın kajdymy Ol'ga vele kajdymy Dashalan tamam forma don ob\#jom gishän saslen popen. Lishküräk tolmykyna, nün̈̈n popymyshty raskydynrak shakten. Kydy-tid̈̈ shajazhym yngylashat lijesh ylyn.

- Am pälb̈ı, ti kvartalyn zavod planym utydon temä ma.

- A anzylgechӹ mastarvlän pogynymashyshty mam popenüt? Mahan' väsheshtb̈ish ylyn?

- Shÿd̈̈ procent jakte shukat kodde, tämdän cehdäm vele izish shypshylash kelesh, manynyt. Talashalda, veremäm idä shypsh.

- Cacenä. Tengechü kürtnim uzhe kanden̈̈t, central'nyj kudyvichüishtb̈ jämvläm kapaenüt. Nel̈̈ yl'y.

- Jara, Ol'ga, päshä kechӹ cilänok tehen'b̈.

- Tenge, a tölät vet kvartirb̈ım pujenb̈t! Susu ylat?

- Susu ylam.

- Kynam b̈läsh vanzhendä? Tagynamok?

- Kyshkyzhmynok i vanzhennä. Kvartira cilä shotyshtat jazho, kuhnjashty vele särnäläshät vär uke. Dä amasa kÿshnӹ kogo shelüık uly, tüı̈̈̈m pitb̈räsh kelnezhü, mün' gün' pydamat seväl pyren am kerd.

b̈ld̈̈rämäshvlä tengeok u garnituryn äkshӹ gishän dä toshty garnitur manjarash ylmy gishän popen̈̈t. Nün̈̈n pyshyshty, koje v̈̈län tygydy kyjrym koden, vӹd tür güc olen karangyn.

Tura kechüıvälün shokshy kechüjalvlä känb̈shb̈̈vläm cilä väreok monyt. Lach tagyce-änjat tishäk kushkyn

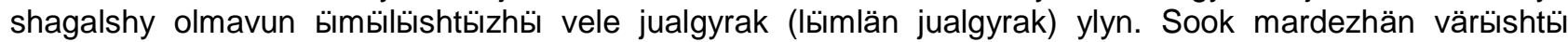
shalgymashesh olmavu tüng jagylgen shüinz̈̈n dä karandash gan' tör, jaklaka ylyn. Mä ladnan vb̈id tüır mychky ashkedüinnä dä trÿk shaldyrgen vacshy shalym uzhyn koltennä. Sarikä oshma vӹln̈̈ tb̈id̈̈ shimün kajyn kijen dä mündüırcok sünzäshkü kerb̈ltẗ̈n. Tünämok süinzä anzyky tolyn: kol chüngümm̈̈m cärnӹmӹı̈̈̈, kollojec tylypshy vülän vazesh, kalpakshym lepkäshküızḧ̈ shükälesh, kidshüım vuj

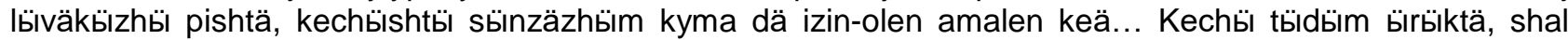
vülväl jylaten koltash shokshy lijesh, no mämnän kollojecnä nimat ak shizh - viänen vazyn, shokshy godym amalalash jarata. Münd̈̈rc uzhat dä shanaltet: «Zhivojok väl?» Shalyn catkydy hangavläzhӹ jeche shuky i tyrhat yl'y, no ves zhep tolyn shagalyn. Kü̈z̈̈t tangyzhysh kol kychash catkydy, b̈njan sudno läktesh. A tangyzh tyrym jamda. Vashtalt shalgyshy mardezh kojevlä mychky rampyn jargata tyl postol kechü sharvläm nängeä. Tärvän̈̈shü koje süln̈̈n kushtyshy jedem semün' mahan'-günjat nÿshẗ̈lshün jalyshkyzhy tolyn töknä dä möngesh tangyzhysh vb̈sä.

Mä tokyna pörẗ̈ll̈̈nä, a vadesh chb̈chem doky kenä. Cḧ̈ichem ladna jedem ylesh, kymyldymy ylmyzhym shojen vele uzhash väreshtesh. Tonyzhy jeche sola gücok kandymy koti ̈̈lä, dä iktb̈ vele agyl. Kostan zhivotnyj agylep günjat, shüren ydyrat. Kugizhä semün' kvartira mychky kashtyt, shokshyrak stenä sagashy lykyshty älät dä pajym vele kachkyt. Küzüt chüichemün yshyzhy shakte gan', tenge günjat shajyshtmashvläzhü sook interesnyjvlä ylyt - tüdd̈̈ b̈shke pälı̈ımäshüzzḧ̈m shüm pecät shajlny ak kychy. Mä küdezhüsh pyrenä dä nüizhülg̈̈ küizhgü jukym kolyna:

- Pury lizhü! Tä mün'b̈ım äshündäredä? Shukerdshen väshlidelna! Iktä b̈ndeksh i jerten, tenge?

Mӹn' török ti jedemüm pälem - hot'-ma lizhӹ günjat, so ikan'ok ylesh. Tüdün tüıng ajyrtemzhӹ ̈̈ll̈̈mäshı̈mm uly shÿm vasht jaratymash. Tehen' ̈̈ll̈̈zhẗ̈ı̈sḧ̈ vizḧ̈ dono tid̈̈ cÿdä agyl!

b̈ll̈̈mäsh yshetüm shukemden? Cäshümm kyce äklet? Iktä-ma gishän günjat ̈̈zhäläet ma? Kyshky kashtyn särnet? Mahan' knigävläm lydynat?

Müläm jadmash vülän jadmashym puat. Koti sünzäzhüım kyma. Sakojym äshündären, shuky veremä shajyshtash töngälb̈nä.

\section{OPINION AND DISCUSSIONS}

The particular quality of a consonant depends on the work of the vocal cords, the position of the soft palate and the kind of noise that results when the tongue or the lips obstruct the air-passage. There are two types of articulatory obstruction: complete and incomplete. 
In this article, Hill Mari consonants will be classified according to the following principles: according to the type of obstruction and the manner of the production of noise; according to the active speech organ and the place of obstruction; according to the work of the vocal cords and the force of articulation; according to the position of the soft palate.

According to the type of obstruction Hill consonants are divided into occlusive and constrictive. Occlusive consonants are produced with a complete obstruction formed by the articulating organs, the air-passage in the mouth cavity is blocked.

Occlusive consonants may be: noise consonants and sonorants. According to the manner of the production of noise occlusive noise consonants are divided into stops and affricates. In the production of affricates the speech organs form a complete obstruction which is then released so slowly that considerable friction occurs at the point of articulation [L], [4'].

In the production of occlusive sonorants the speech organs form a complete obstruction in the mouth cavity which is not released. Constrictive consonants are produced with an incomplete obstruction. Constrictive consonants have been divided into noise consonants (or fricatives) and sonorants. We can say that vowels are shorter before all voiceless consonants than before all voiced consonants. In this way, we can capture linguistically significant generalization one dealing with stops and the other dealing with fricatives. We also distinguished that a voiceless stop at the end of a syllable as in sum is longer than the corresponding voiced stop as in $\kappa u d$.

We first have analyzed the behavior of voiced and voiceless consonants in the initial position (the beginning of a syllable, of a word) and then in the final position (the end of a word, of a sentence). Our material shows that initial voiced consonants are pronounced as voiceless: каранцын is actually каранкын; final voiceless consonants /п, т, к, ч/ are longer than voiced /б, д, г, ж]: шайыштмашвлӓж(ы).

It was very interesting to know that Hill Mari voiced consonants tent to be devoiced in the final position and partially devoiced in the initial position.

The fricatives of Hill vary less than the stop consonants, yet the major allophonic variations that do occur are in many ways similar to those of the stops. Fricatives differ from stops in that they sometimes involve actions of the lips that are not immediately obvious.

We also tried to review the status of affricates [c] [č] in Hill Mari. An affricate is simply a sequence of a stop followed by a homorganic fricative. They are the only affricates in Hill Mari that can occur at both the beginning and the end of words: цӹвӹ 'hen', цацышыц 'уоu tried', циц 'full', чӓс 'time', чуч 'hit'.

According to the active organ of speech Hill Mari consonants are divided into labial, lingual and glottal.

Labial consonants are subdivided in bilabial and labio-dental.

Hill Mari bilabial consonants are articulated by the two lips: [n], [б], [M].

Labio-dental consonants are articulated with the lower lip against the upper teeth. The Hill Mari labio-dental consonants are [ф]], [B].

Lingual consonants are divided into fore-lingual, medio-lingual, and back-lingual.

Fore-lingual consonants are articulated by the blade of the tongue, the blade with the tip or by the tip against the upper teeth or the alveolar ridge. According to the position of the lip Hill Mari fore-lingual consonants may cacuminal. The following consonants [T], [T'], [A], [H], [H'], [C], [p] are dorsal.

Apical consonants are articulated by the tip of the tongue against either the upper teeth or the alveolar ridge, [л], [л'], [ш], [ж]. Cacuminal consonant [р] is articulated by the tongue tip raised against the back part of the middle alveolar ridge.

The Hill Mari medio-lingual consonant [ $\breve{h}]$ is articulated with the front of the tongue against the hard palate.

The Hill Mari back-lingual consonants $[\mathrm{K}],[\mathrm{r}],[\mathrm{x}]$ are articulated by the back of the tongue against the soft palate.

According to the point of articulation fore-lingual consonants are subdivided into dental (interdental or postdental), alveolar, palato alveolar, and post-alveolar.

Dental consonants are articulated against the upper teeth either with the blade of the tongue, the Hill Mari [л], [л'], [т], [т']. It is worth mentioning that the consonant [т'] is not produced in Meadow Mari. 
Alveolar consonants are articulated by the tip of the tongue against the alveolar ridge: [p]. Palato-alveolar consonants [ய], [ж] are articulated by the tip and blade of the tongue against the alveolar ridge or the back part of the alveolar ridge, while the front of the tongue is raised in the direction of the hard palate.

According to the point of articulation medio-lingual and back-lingual consonants are called palatal and velar.

According to the work of the vocal cords consonants are divided into voiced and voiceless. According to the force of articulation consonants are divided into relatively strong, and relatively weak.

The following Hill Mari consonants are voiceless: [p], [t], [t’], [k], [g], [f], [s], [š], [ $\square$ ]. These Hill Mari

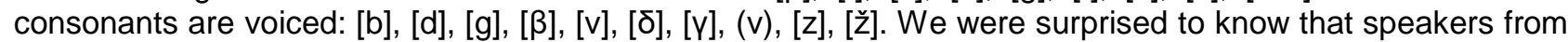
the village of Mikryakovo the Hill Mari voiceless consonants [p], [t], [k] are pronounced with aspiration, especially before a stressed vowel.

Hill Mari voiceless consonants are weaker than their Russian counterparts (Zorina, Krasnova, 2020).

According to the position of the soft palate consonants are divided into oral and nasal.

Nasal consonants are produced with the soft palate lowered while the air-passage through the mouth is blocked. The Hill Mari nasal consonants are [M], [H], [H'], [n]. The authors proved that the back-lingual stop sonant [ $\mathrm{n}$ ] in the Hill Mari language is a full-fledged and self-sufficient phoneme. It occurs in words before the consonant and at the end of the word. For example, шонгла [šolla] "like a foam" - шотла [š'otla] "he counts", тонг [ton] "a pip" - топ [top] "a ball". The limitation of its distribution is at the very beginning of the word, at the beginning of the syllable, and between vocals (Zorina, Krasnova, 2020).

Nasals can be syllabic when they occur at the beginning or end of words. The nasal [ $\mathrm{\eta}$ ] differs from the other nasals in a number of ways. No Hill Mari word can begin with [n]. It is worth mentioning that [n] is used in Meadow Mari quite often. This sound can occur only within or at the end of a word, and even in these circumstances it does not behave like the other nasals. It can be preceded only by the vowels /ä, b̈, a, a, э/

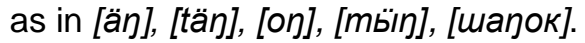

Oral consonants are produced when the soft palate is raised and the air escapes through the mouth.

The following Hill Mari consonants are oral [п], [п'], [б], [т], [т'], [д], [к], [ф], [в], [с], [с'], [3], [ш], [ж], [ц], [л], [л'],

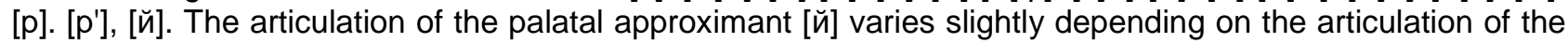
following vowel (Gruzov, 1965).

Consonants were classified in terms of the following factors:

- State of the vocal folds (voiced or voiceless)

- Position of the soft palate (nasal or oral)

- Place of articulation (labial, coronal, dorsal, glottal)

- Manner of the production of noise (stops, fricatives, approximants).

\section{ACKNOWLEDGEMENT}

This research was financially supported by the Russian Foundation of Basic Research (Grant NO. 20-01200481 A).

\section{REFERENCE LIST}

Gruzov, L.P. (1965). Phonetics of Dialects of the Mari language in Historical Coverage.

Zorina, Z.G., Krasnova N.M. (2020). About the Importance of Two Hill Mari Phonemes in Language Education of Future Hill Mari Teachers Abstracts \& Proceedings of ADVED 2020-6th International Conference on Advances in Education, 5-6 October 2020. Pp. 383-387 DOI: https://doi.org/10.47696/adved.202078 ISBN: 978-605-06286-0-9 